\title{
Impacts of Hurricane Damage on Southern Highbush Blueberries $^{1}$
}

\author{
Douglas A. Phillips, Jeffrey G. Williamson, and Philip F. Harmon ${ }^{2}$
}

Florida has been affected by eight hurricanes since 2000 . As of this article's writing, Hurricane Michael was the most recent storm to affect the state (October 2018) with sustained wind speeds of $160 \mathrm{mph}$ at the time of landfall. In 2017, Hurricane Irma hit the Florida peninsula with winds up to $112 \mathrm{mph}$ and accumulated rainfall of up to 14 inches. Both Irma and Michael caused significant property damage across the state, including damage to agricultural crops. For Irma alone, over 5.0 million acres of cropland were affected, including 3.4 million under hurricane-force winds. Total crop sales losses have been estimated in excess of $\$ 1.5$ billion. This publication discusses the types of hurricane damage incurred in blueberry production operations, the impacts of these damages, and some recommendations on best management practices in the aftermath of a storm.

\section{Wind Damage}

Hurricane-force winds are sustained winds of at least $74 \mathrm{mph}$, which can increase to more than $156 \mathrm{mph}$ with a Category 5 storm. Winds of this magnitude, or even tropical storm-force winds (between 39 and $73 \mathrm{mph}$ ), can cause significant damage to blueberry plants, including defoliation and uprooting plants.

Defoliation can have a significant impact on blueberry production even before there are blossoms or fruit on the plants. Flower bud number is the most important characteristic of yield in blueberries. This is determined by the amount of flower bud initiation and development that takes place in late summer and fall, which depends on plants having a full and healthy canopy of foliage. Early fall (September and October) defoliation of southern highbush blueberry reduces the number of flower buds that develop and/or the number of fruit produced per flower bud, and it can also affect bloom time. The impact of defoliation on yield could be even more significant on blueberry plants grown in an evergreen system, where it is important to maintain healthy foliage throughout the fall, winter, and early spring to support the next year's crop and to achieve early yields of high-quality fruit. The blueberry defoliation that can occur during a hurricane can thus have a major impact on the following season's crop.

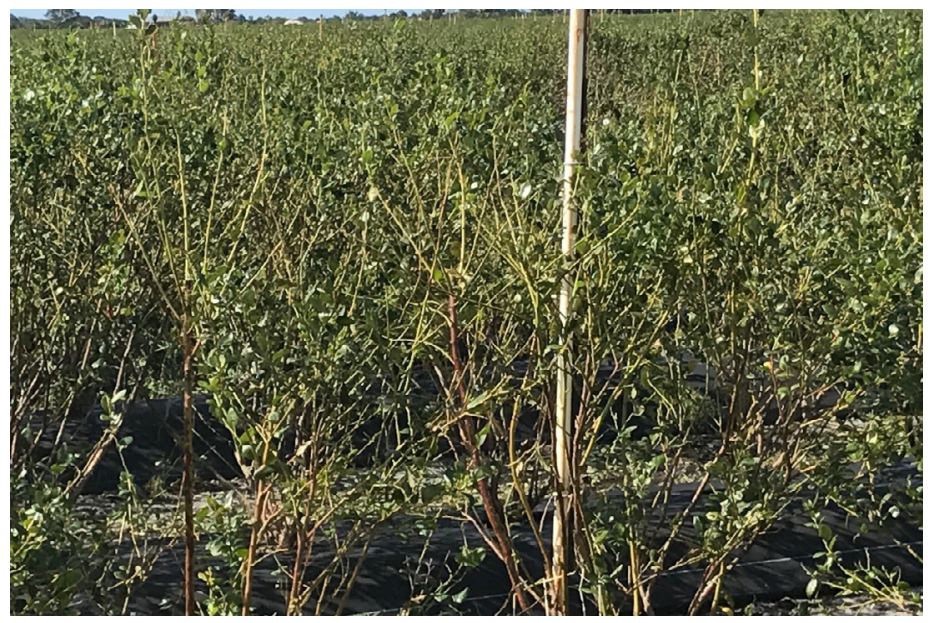

Figure 1. Blueberry plants defoliated during Hurricane Irma. Credits: J. Gross

1. This document is HS1342, one of a series of the Horticultural Sciences Department, UF/IFAS Extension. Original publication date September 2019. Visit the EDIS website at https://edis.ifas.ufl.edu for the currently supported version of this publication.

2. Douglas A. Phillips, blueberry Extension coordinator; Jeffrey G. Williamson, professor, Horticultural Sciences Department; and Philip F. Harmon, professor, Plant Pathology Department, UF/IFAS Gulf Coast Research and Education Center, Wimauma, FL 33598.

The Institute of Food and Agricultural Sciences (IFAS) is an Equal Opportunity Institution authorized to provide research, educational information and other services

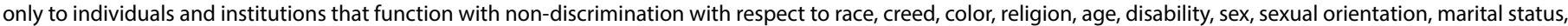

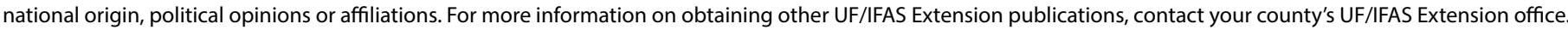
U.S. Department of Agriculture, UF/IFAS Extension Service, University of Florida, IFAS, Florida A \& M University Cooperative Extension Program, and Boards of County Commissioners Cooperating. Nick T. Place, dean for UF/IFAS Extension. 
Hurricane-force winds can also cause damage by uprooting blueberry plants. In addition to the need to reset and stake these plants, potential breakage of woody stems and the root system can significantly impair transport of water and nutrients throughout the plant, which results in delayed, stunted growth and serious plant stress that can persist for weeks or even months. Wounds also provide entry points for several stem and root pathogens. Severe plant stress often leads to significant outbreaks of Botryosphaeria stem blight, sometimes months after the wind damage and plant stresses occur.

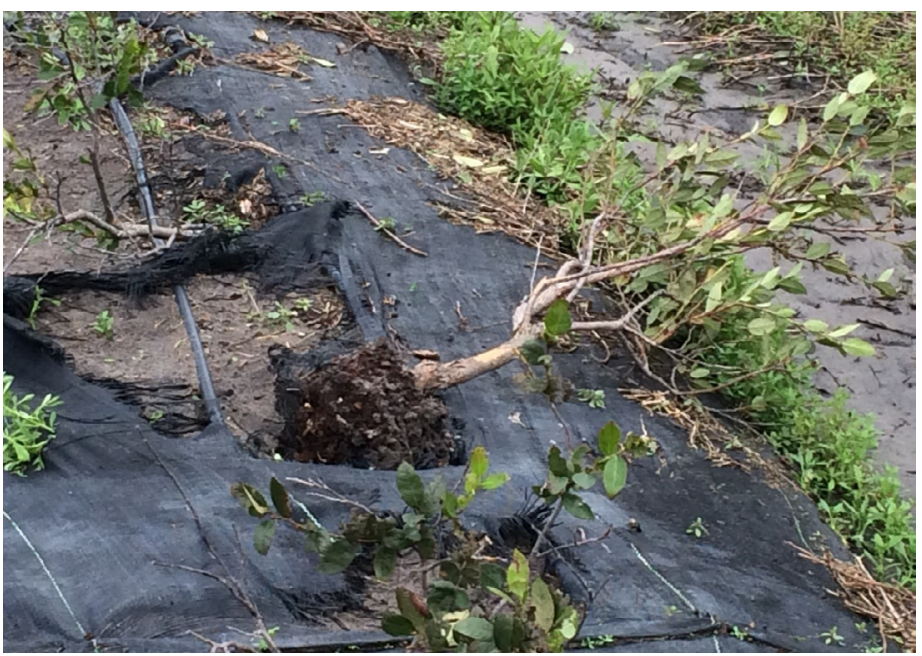

Figure 2. Blueberry plants uprooted during Hurricane Irma.

Credits: J. Gross

\section{Flooding}

Flooding from a hurricane or tropical storm can create multiple problems for blueberries, because there can be standing water in the fields for several days following a significant storm. Blueberry plants generally do not tolerate saturated conditions well.

Root death can occur when there is no oxygen in the root zone due to saturated conditions (hypoxia). Flooding can reduce root and shoot growth, reduce leaf number, inhibit leaf expansion, increase leaf abscission, reduce nutrient uptake, and result in smaller flower buds and fruit. Each of these factors can have a detrimental impact on the following season's yield. Minimizing the length of time that flooded conditions persist by pumping water from the field may help to limit this damage. One disease in particular that thrives in flooded conditions is Phytophthora root rot. The water mold pathogen Phytophthora cinnamomi has swimming zoospores that spread readily through surface water, and saturated conditions with root wounding are an ideal scenario for infection of blueberry roots by these spores.

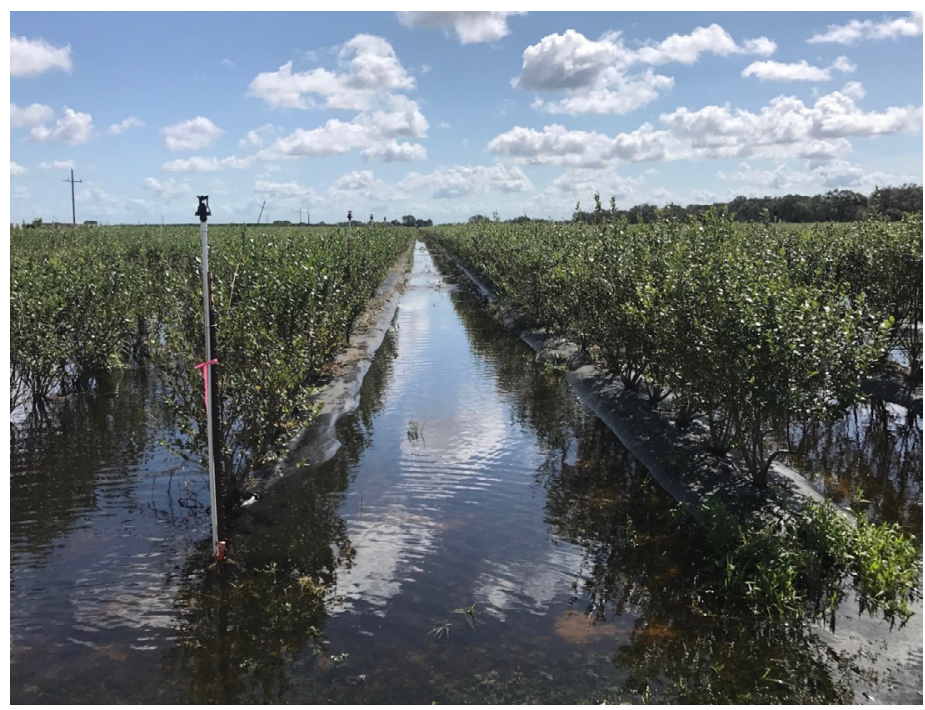

Figure 3. Flooded blueberry field following Hurricane Irma. Credits: J. Gross

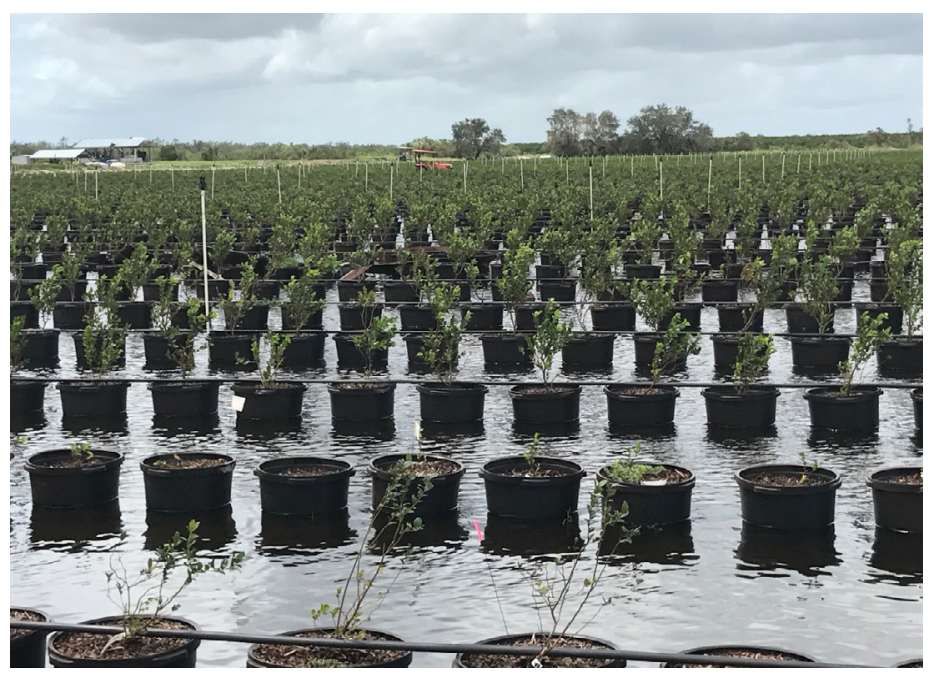

Figure 4. Flooded blueberry container production after Hurricane Irma.

Credits: J. Gross

\section{Disease}

The three factors that must be present for plant disease are an active pathogen, favorable environmental conditions for disease development, and a susceptible host. Each of these factors can be affected by a hurricane.

Pathogen-High winds and rising waters can spread the pathogens into and throughout a production field to areas where they may not have been present previously.

Environment-flooded soils and extended rain events associated with a major storm, along with the hot and humid weather typical for Florida during summer and early fall, are ideal conditions for successful pathogen infections into blueberry plants. These same conditions also promote post-infection symptom development and continued spread of many blueberry diseases. 
Plant Host-blueberry plants that suffer the types of storm damage discussed above are considerably stressed. Stressed and wounded plants have fewer defenses against pathogen infection and disease development. Diseases like Botryosphaeria stem blight often become much more prevalent in a field of stressed plants, and stressed plants are also more likely to die from the disease when it occurs compared to fields not stressed by storm damage and conditions.

\section{Recommendations}

The recommended approach in the aftermath of a hurricane is the consistent application of best management practices to alleviate or avoid additional plant stress. Reset and stake uprooted lodged plants as quickly as possible to reduce losses from desiccation and plant death. Examine irrigation systems to make sure that when waters recede, the system is functioning properly. Carefully monitoring irrigation after the storm and rains pass will be critical to preventing further drought stress in plants with damaged root systems. Repair raised beds and weed cloth, and resume bed irrigation and $\mathrm{pH}$ monitoring, adjusting as necessary. Resume scheduled fertilizer applications after waters have receded and when beds begin to drain, but consider reducing rates of nitrogen where plants have been stressed, slowly returning to recommended timings and rates for the given deciduous or evergreen production system.

Another important practice is to resume scouting for disease symptoms and insect pests and to begin to apply management and control recommendations as appropriate. See EDIS Publication HS1156, 2019 Florida Blueberry Integrated Pest Management Guide (http://edis.ifas.ufl. edu/hs380). Ideally, applications of Ridomil or another mefenoxam fungicide for Phytophthora root rot prevention will have already been made in early summer prior to hurricane activity. Two applications of these products per year are allowed, and where a second application was not made earlier, consider making that application prior to a predicted storm impact where possible. When not possible, the second application can be made after waters have receded either in a banded bed application or through certain irrigation systems (consult the product label for specifics). These applications can help prevent root rot development, but they will not cure plants severely affected or those dying from flooding (hypoxia).

Good recordkeeping is also important to document any losses suffered, including detailed production records from prior years and pictures and video of all areas of the farm affected by the storm.

\section{References}

Clouser, R., A. Hodges, C. Court, J. Vansickle, and S. Stefanou. 2017. Impacts of Hurricane Irma on Florida Agriculture: Update \#4. UF/IFAS Food and Resource Economics Department.

Kovaleski, A., J. Williamson, J. Olmstead, and R. Darnell. 2015. "Inflorescence Bud Initiation, Development, and Bloom in Two Southern Highbush Blueberry Cultivars." J. Amer. Soc. Hort. Sci. 140(1): 38-44.

NOAA Tropical Winds Newsletter - Fall 2017 (http://noaa. maps.arcgis.com/apps/MapJournal/index.html?appid=c712 badd484c4a9d8dbaa3692ba7d1fe)

Schaffer, B., P. Andersen, and R. Ploetz. 1992. "Responses of Fruit Crops to Flooding.” Florida Agricultural Experiment Station Journal Series No. R-00613:257-313.

Williamson, J., P. Lyrene, and E. Miller. 2003. "Early and Mid-Fall Defoliation Reduces Flower Bud Number and Yield of Southern Highbush Blueberry." Proc. Fla. State Hort. Soc. 116: 25-27. 